\title{
VIVÊNCIAS E IMAGENS SOBRE O LAZER NA PERSPECTIVA DE IDOSAS COM DOENÇA CELÍACA ${ }^{1}$
}

Recebido em: 19/02/2020

Aprovado em: 14/09/2020

Licença:@) (1) @

\author{
Priscila Mari dos Santos Correia ${ }^{2}$ \\ Universidade Federal de Santa Catarina (UFSC) \\ Florianópolis - SC - Brasil \\ Alcyane Marinho ${ }^{3}$ \\ Universidade Estadual de Santa Catarina (UESC) \\ Florianópolis - SC - Brasil
}

RESUMO: O trabalho objetiva apresentar as vivências no lazer e as imagens sobre ele na perspectiva de idosas com doença celíaca. O estudo tem abordagem qualitativa e características descritivo-exploratórias. Está pautado na sociologia compreensiva e do quotidiano de Michel Maffesoli. A estratégia metodológica da história de vida tópica orientou a coleta de dados. Participaram nove idosas, com média de idade de $67 \pm 6,6$ anos, residentes em Florianópolis/SC, São José/SC e Governador Celso Ramos/SC. Utilizaram-se entrevista em profundidade e diário de campo. Utilizou-se o modelo de análise qualitativa de Schatzman e Strauss. O lazer foi associado a imagens variadas, mas contemplando as próprias vivências ocorridas nesse âmbito, que, por vezes, são limitadas pelo tratamento da doença celíaca, especialmente as vivências sociais. Imagens e vivências foram abordadas pelas idosas considerando aspectos sensíveis diversos.

PALAVRAS-CHAVE: Atividades de Lazer. Idosos. Doença Celíaca.

\section{EXPERIENCES AND IMAGES ABOUT LEISURE IN THE PERSPECTIVE OF ELDERLY PEOPLE WITH CELIAC DISEASE}

ABSTRACT: This study to describe their experiences and the participants imaginarium about the leisure it from the perspective of elderly women with celiac disease. The study's approach was qualitative and it involves descriptive-exploratory characteristics. Based on the comprehensive and everyday sociology of Michel Maffesoli. The topological life history method guided data collection. The sample included 9 older women, with a mean age of $67 \pm 6.6$ years, in Florianópolis, São José or Governador

\footnotetext{
${ }^{1}$ Este trabalho integra uma pesquisa mais ampla, desenvolvida como tese de Doutorado da primeira autora, a qual recebeu auxílio financeiro por meio do Programas de Bolsas Universitárias de Santa Catarina - UNIEDU.

2 Doutora, Universidade Federal de Santa Catarina (UFSC), Laboratório de Pesquisa em Lazer e Atividade Física (LAPLAF).

${ }^{3}$ Doutora, Universidade do Estado de Santa Catarina (UDESC), Laboratório de Pesquisa em Lazer e Atividade Física (LAPLAF).
} 
Celso Ramos, Brazil. In-depth interviews and field diaries were used. Schatzman and Strauss' field research method of qualitative analysis was used. Leisure describes various experiences and images that involve sensitive aspects, which are sometimes limited by the treatment of celiac disease.

KEYWORDS: Leisure Activities. Aged. Celiac Disease.

\section{Introdução}

A sociedade contemporânea, pós-moderna, apresenta diferenças expressivas em relação às características da modernidade, gerando variadas ressonâncias sobre a vida quotidiana das pessoas. O trabalho, embora não tenha perdido seu poder, abriu espaço para outras esferas da vida, para a valorização do presente, especialmente do vivido e do sentido em comum (BRUHNS, 2002, 2009; MAFFESOLI, 2012, 2016).

Se, na modernidade, o produtivismo foi a ideologia dominante de um indivíduo que lutava por um progresso econômico para o alcance de um bem futuro, parece lógico, como consequência dessa época, o ser humano envelhecido ter sido associado aos signos da improdutividade e do descartável (DEBERT, 2011; DEBORTOLI, 2012). Do mesmo modo, parece razoável para o pensamento dominante naquele momento histórico-social, o lazer ter sido visto como mero atenuador das tensões do trabalho, a fim de que, com mais tranquilidade e energia, o retorno a ele em prol de um "bem" maior pudesse ser estabelecido (BRUHNS, 2004, 2009).

Entretanto, esse projeto de futuro parece não ter sido bem-sucedido, sendo que essas lógicas e razões cederam espaço para outros valores e significados para os mesmos assuntos (BRUHNS, 2002; MAFFESOLI, 2016). Assim, temas como envelhecimento humano e lazer expandiram-se para a consideração de aspectos quotidianos, incluindo práticas e representações sociais, assim como diferentes modos de ser, de pensar, de amar, de trabalhar, de se divertir (BRUHNS, 2002). 
Surgiu espaço, inclusive, para imagens mais positivas sobre o processo de envelhecimento, abrindo espaços para vivências diversas no lazer, valendo-se de um suposto tempo disponível dos idosos para "melhor" viverem e satisfazerem desejos variados (DEBERT, 2010; DEBORTOLI, 2012). Todavia, ao reconhecer que isso não se concretiza em todos os casos, pois o envelhecimento é envolvido por múltiplos fatores (sociais, econômicos, políticos, culturais, etc.), abarcando contradições, relações e condições sociais distintas, representações diversas, potências e limites (BRITTO DA MOTTA, 2012, 2013; DEBERT, 2010, 2011, 2013; DEBORTOLI, 2012; PICCOLO, 2011), é que ele foi entendido como um processo inerente à condição de existência humana, que envolve diferentes mudanças e distintas formas de vivenciá-las, abrangendo, inclusive, o lazer (DEBORTOLI, 2012).

Falar em lazer, em tempos pós-modernos, é mergulhar nas profundezas de significados múltiplos e complexos. Dependendo do interlocutor e do ser que o vive, do local de onde se fala, da dinâmica cultural em que se está inserido, o lazer assume sentidos diferentes. Diante disso, ele pode ser pensado como território da vida quotidiana, onde se enraízam prazeres, alegrias, tristezas, frustações, emoções, sonhos, afetos, medos, imagens (MAFFESOLI, 1998, 2009).

Essa possibilidade compreensiva sobre o lazer, que inclui parâmetros sensíveis em sua abordagem e não o delimita em um conceito fechado e sustentado pelo tempo de não trabalho ou de outras obrigações, abre espaço para revelar desejos, anseios e valores contemporâneos, contribuindo para a sua compreensão na pós-modernidade (BRUHNS, 2002). Dessa forma, o lazer pode ser entendido, em suma, em uma perspectiva de relação com a vida (BRUHNS, 1999), podendo ser focalizado no contexto dos idosos ao se considerar a variedade de processos de relações e de envolvimentos que essas pessoas apresentam ao longo de suas histórias de vida (DEBORTOLI, 2012). 
Conforme tem sido indicado por diferentes pesquisas, nesse processo de relação com o mundo os idosos vivenciam atividades diversas no lazer, como leituras, viagens, danças, esportes, atividades físicas, de cunho espiritual, de aventura na natureza (COUTINHO; ACOSTA, 2009; SANTOS; MARINHO, 2015; VISCARDI et al., 2018), incluindo aquelas frequentemente relegadas a segundo plano pela lógica instrumental dominante na modernidade, como a arte, a poesia, a música, a imaginação, o sagrado, entre outras (DEBORTOLI, 2012); embora, em muitos casos, todas elas possam ser envolvidas por limitações (dificuldades financeiras, estereótipos, etc.) (COUTINHO; ACOSTA, 2009; MELLO; VOTRE, 2013; SANTOS, 2015), incluindo, também a possibilidade de limitação por situações de adoecimento.

Nessa direção, destaca-se a doença celíaca; enfermidade que acomete em torno de $1 \%$ da população mundial, com variações entre os países, mas incluindo todas as faixas etárias (GREEN; LEBWOHL; GREYWOODE, 2015). Trata-se de uma desordem imunomediada sistêmica, desencadeada pelo glúten e prolaminas relacionadas, em pessoas geneticamente susceptíveis. Caracteriza-se pela presença de manifestações clínicas dependentes do glúten, antígeno leucocitário humano (HLA) DQ2 e HLA - DQ8, anticorpos específicos, e enteropatia (HUSBY et al., 2012).

Os sintomas podem surgir em qualquer fase da vida e mesmo variar ao longo dela (WORLD GASTROENTEROLOGY ORGANISATION, 2012), diferenciando-se em quatro categorias de manifestações clínicas: 1) clássica, quando há má absorção intestinal, com presença de diarreia, perda de peso, entre outros; 2) não clássica, quando há sintomas como constipação e dor abdominal, mas não sinais de má absorção intestinal; 3) subclínica, quando os sintomas são exclusivamente extra intestinais (anemia, osteoporose, entre outros); 4) assintomática, quando não há os sintomas da doença (LUVDIGSSON et al., 2013). 
O único tratamento disponível até o momento é a retirada do glúten por toda a vida (BRASIL, 2015; HUSBY et al., 2012; WORLD GASTROENTEROLOGY ORGANISATION, 2012). O glúten constitui-se em um complexo protéico encontrado no trigo e de prolaminas relacionadas: a hordeína encontrada na cevada e a secalina, no centeio (LUDVIGSSON et al., 2013).

Embora possa parecer simples a mera exclusão de um ingrediente, múltiplos hábitos são modificados com este tipo de dieta (MOORE, 2014), trazendo diferentes implicações à vida quotidiana, especialmente restrições sociais. Há dificuldades envolvendo as relações sociais fora de casa, na escola, no trabalho, no lazer, especificamente na participação em festas e reuniões familiares, eventos sociais diversos, atividades turísticas, entre outras possibilidades (LORENZO, 2010; NASCIMENTO; FIATES; TEIXEIRA, 2017; SVERKER; HENSING; HALLERT, 2005).

De acordo com Vilppula et al. (2008), isso se torna particularmente importante no contexto da população idosa, devido à sua probabilidade de mortalidade aumentada, notadamente em decorrência da idade avançada e do desenvolvimento de doenças associadas como complicações da doença celíaca. Essas complicações incluem cânceres diversos, infertilidade não explicada, osteoporose, cardiopatias, diabetes mellitus tipo 1, entre outras (BROUSSE; MEIJER, 2005; COSNES; NION-LARMURIER, 2013; CRANNEY et al., 2005; LUDVIGSSON et al., 2013; WORLD GASTROENTEROLOGY ORGANISATION, 2012).

Além disso, esses impactos sociais se tornam relevantes pelo fato de os idosos caracterizarem um grupo populacional frequentemente identificado como vivendo em condições que envolvem abandono e negligência (BRITTO DA MOTTA, 2013); perda de familiares e solidão (PICCOLO, 2011); e dificuldades de acesso a determinados 
espaços e iniciativas voltados ao lazer (COUTINHO; ACOSTA, 2009; MELLO; VOTRE, 2013; SANTOS, 2015).

Ademais, essa situação torna-se ainda mais instigante quando se observa a pouca quantidade de estudos específicos sobre idosos com doença celíaca no Brasil (ALMEIDA, 2012; PEREIRA; CORRÊA; HALPERN, 2006) e no mundo (GASBARRINI et al., 2001; LOBO et al., 2004; VILPPULA et al., 2008). As poucas pesquisas existentes, entretanto, mostram que essas pessoas existem, sendo que algumas delas, inclusive, participaram de estudos nacionais (KOTZE, 2009; NASCIMENTO, 2014; RIBEIRO et al., 2017) e internacionais (HANKEY; HOLMES, 1994; IVARSSON et al., 1999) sobre aspectos diversos acerca dessa doença.

Se há estudos indicando haver, de algum modo, impactos na vida de pessoas com doença celíaca em decorrência da restrição alimentar que lhes é imposta a partir do diagnóstico, incluindo-se, nesses casos, os idosos, torna-se importante considerar os diferentes aspectos envolvidos no quotidiano dessas pessoas; dentre eles, as vivências no lazer e as imagens sobre ele. Nessa direção, este trabalho, que integrou uma pesquisa mais ampla desenvolvida como tese de doutorado da primeira autora, tem como objetivo apresentar as vivências no lazer e as imagens sobre ele na perspectiva de idosas com doença celíaca.

Conforme Maffesoli (1998), as vivências, sob suas diversas modulações, possibilitam a razão, legitimando-a de certo modo. Por integrarem maneiras de ser e envolverem aspectos sensíveis (paixões, emoções, afetos, entre outros) possibilitam o enriquecimento do saber. As imagens, por sua vez, também segundo Maffesoli (2016), integram um "mundo imaginal" em que a prevalência do simbólico traz à tona um imaginário sobre algo, caracterizando uma eficácia própria das ideias que garante. 
Desse modo, o imaginário envolve não apenas aquilo que vemos, mas o que sentimos e pensamos sobre certos aspectos da vida (MAFFESOLI, 2010); entre eles, o lazer.

\section{Metodologia}

A pesquisa realizada teve abordagem qualitativa (MINAYO, 2008) e características descritivo-exploratórias (GIL, 2008), sendo sustentado teoricamente pela sociologia compreensiva e do quotidiano apresentada na obra de Michel Maffesoli (2010). A estratégia metodológica da história de vida tópica orientou a coleta de dados (MINAYO, 2008).

A sociologia compreensiva e do quotidiano é apresentada por Maffesoli (2010) como um método "aberto" que permite uma abordagem indutiva, estruturalmente tolerante, fundamentalmente adogmática, essencialmente relativista. Busca nada mais que apresentar as coisas, preocupando-se mais com o "como" do que com o "por que", mas sem a pretensão de invalidar este último. Sua exigência intelectual consiste em identificar o sentido simbólico, adequando-se, assim, aos estudos com abordagem qualitativa e também com características descritivo-exploratórias.

A estratégia metodológica da história de vida, por sua vez, é descrita por Minayo (2008) como pertinente no contexto de estudos que visam à descoberta, à descrição e à compreensão de aspectos do quotidiano das pessoas, em determinado tempo e espaço. No presente estudo, o tempo-espaço em foco foi o quotidiano, o viver diário, o aqui e o agora, mas recuperando alguns aspectos quotidianos de tempos-espaços anteriores que se conectam ao momento presente.

Conforme Minayo (2008), em uma pesquisa que utiliza essa estratégia metodológica os participantes narram uma versão situada de episódios, que podem cobrir toda a sua história, ou incluir apenas alguns tópicos sobre ela, conferindo ênfase a 
algumas etapas ou setores da vida pessoal. Neste caso, a estratégia metodológica em questão pode ser chamada de história de vida tópica ou focal, tendo sido utilizada neste estudo por meio da focalização de tópicos que incluíram as vivências no lazer e as imagens sobre ele na perspectiva de idosas com doença celíaca.

Para selecionar essas pessoas, foi utilizada a técnica de amostragem intencional denominada "bola de neve", a qual utiliza cadeias de referência para encontrar os integrantes do estudo (BERNARD, 2006). As referências foram variadas, incluindo tanto pessoas com características profissionais diversas (discentes, docentes, profissionais da área da saúde), quanto espaços de divulgação físicos (estabelecimentos comerciais sem glúten, clínicas de gastroenterologia, associação de pessoas com a doença, etc.) e virtuais (grupos de apoio à doença celíaca organizados no Facebook, páginas sobre a doença, etc.). Foram identificadas 11 pessoas com as características desejadas no período de janeiro a julho de 2019, tendo havido duas recusas para participação na pesquisa por falta de tempo e falta de interesse.

Havia sido estabelecido como critérios de participação na pesquisa: pessoas idosas, com 60 anos ou mais de idade; residentes preferencialmente na região da Grande Florianópolis (SC); com diagnóstico de doença celíaca há, pelo menos, um ano. As nove pessoas que aceitaram participar do estudo são do sexo feminino, residentes nos municípios de Florianópolis (SC), São José (SC) ou Governador Celso Ramos (SC), apresentando média de idade de $67 \pm 6,6$ anos, tendo a mais nova 60 e a mais velha 79 anos. Diante disso, torna-se evidente que o fato de as nove idosas serem do sexo feminino ocorreu casualmente, não tendo havido delimitação por sexo para participar do estudo.

Os dados foram coletados por meio da utilização combinada de dois tipos de instrumentos: 1) entrevista em profundidade, também chamada de entrevista aberta ou 
não estruturada; 2) diário de campo, entendido como instrumento de trabalho da observação (MINAYO, 2008, 2016).

As entrevistas não seguiram qualquer roteiro físico com perguntas pré-fixadas ou sequência de assuntos a serem abordados. No encontro com cada participante, a entrevista foi assumindo uma forma própria, considerando os assuntos em estudo, dentre eles, as vivências e as imagens relacionadas ao lazer. Assim, foi conferida atenção à escuta de cada participante e às interações necessárias à fluidez do diálogo e/ou ao aprofundamento das narrativas. Os áudios das conversas foram gravados e, depois, transcritos na íntegra pela primeira autora, com correções ortográficas, e validados por cada idosa participante. Totalizaram 14 horas de gravação e 388 laudas de transcrição.

O diário de campo, por sua vez, constituiu-se em um arquivo eletrônico, composto por 65 laudas, no qual foi registrado, sempre após cada entrevista, alguns dos aspectos relacionados à fala das participantes, especialmente no que se refere àqueles que envolveram gestualidades e expressões faciais/corporais que indicavam emoções, reações e modos de agir e de se posicionar relacionadas às palavras verbalizadas sobre determinados acontecimentos da vida das idosas. Além disso, abarcaram as características do contexto de realização da entrevista, por estar envolvido na produção das narrativas. Ambos os aspectos foram organizados como "Notas de Interação", havendo também o registro de "Notas Metodológicas", "Notas Teóricas" e "Notas da Pesquisadora", com base em modelo de anotações proposto por autores como Schatzman e Strauss (1973) e Nitschke (1999).

A coleta de dados foi realizada nos dias, locais e horários escolhidos por cada idosa. Houve aprovação prévia do Comitê de Ética em Pesquisas Envolvendo Seres Humanos da UDESC, sob parecer n. ${ }^{\circ} 2.668 .125$, de 22 de maio de 2018. Cada idosa 
também assinou, em duas vias, um Termo de Consentimento Livre e Esclarecido (TCLE) para a participação no estudo, assim como um termo de consentimento específico para a gravação do áudio da entrevista.

Os dados foram analisados com base no modelo de análise qualitativa e estruturado principalmente pelos próprios dados proposto por Schatzman e Strauss (1973). Com base nesses autores, foi adotada a estratégia de realização de uma análise preliminar por meio do registro de notas no diário de campo e, também, a partir das transcrições das entrevistas, os quais foram efetuados concomitantemente ao período de coleta, possibilitando a familiarização com os dados que estavam sendo obtidos e favorecendo decisões tomadas no decorrer do trabalho de campo. Compôs também essa etapa a organização do corpus da pesquisa no software NVivo, quando foram realizadas leituras repetitivas do material, juntamente à releitura dos objetivos do estudo e do referencial teórico, sendo identificados, preliminarmente, dados que indicavam se associar a classes específicas.

Seguindo, ainda, as orientações de Schatzman e Strauss (1973), na etapa que pode ser considerada como integrante da análise propriamente dita, realizada após o término da coleta de dados, foram sendo nomeadas classes de aspectos contidos no texto transcrito das falas das entrevistas, complementado pelas notas de interação. A partir da identificação dessas classes, de checagem sobre os trechos das falas que as representavam e de formulação de afirmações simples indicativas dos vínculos que as classes poderiam estabelecer entre si, foram sendo realizadas "ligações-chave" até o alcance de um conjunto denso de ligações que permitiu a elaboração de um esquema analítico geral por meio da identificação de categorias de classes.

As categorias finais apresentadas neste estudo referem-se às: 1) vivências no lazer das idosas com doença celíaca; e, 2) imagens sobre o lazer na perspectiva das 
idosas com doença celíaca. Os resultados referentes a essas duas categorias serão discutidos de forma conjunta.

\section{Resultados e Discussões}

Neste estudo, os modos de pensar, de ver, de viver o lazer, espontaneamente apareceram ao longo das entrevistas; mostraram-se, conforme as imagens expressadas pelas palavras das idosas em suas narrativas; de acordo com seu imaginário, suas próprias ideias, opiniões, crenças, valores, expectativas, necessidades, contextos e maneiras de viver. Logicamente, ao serem informadas sobre os objetivos da pesquisa, as idosas previamente tomaram conhecimento que o lazer era um assunto em estudo. Mas, foi falando sobre a vida como um todo, sobre o dia a dia, o quotidiano atual e também sobre o vivido antes e depois da doença celíaca, que a abordagem sobre o lazer emergiu, sendo esse fenômeno, então, significado, imaginado, sentido.

Isso remete ao todo complexo de variados elementos que compõem a vida pósmoderna e permite pensar o lazer neste contexto, com base principalmente em Bruhns (1998, 1999, 2004, 2009) e em Maffesoli (1998, 2009, 2016). Maffesoli (1998, 2009) havia abordado o lazer como território da vida quotidiana. Bruhns $(2004,2009)$, por sua vez, assim como Marinho (2006), também tinham lançado olhares para esse fenômeno no sentido de entendê-lo como um aspecto capaz de aguçar a compreensão sobre as variadas relações estabelecidas entre seres humanos, especialmente quando o lazer é considerado em profunda conexão com as demais dimensões da vida.

Foi possível compreender que, no imaginário das idosas, o lazer, nos tempos de hoje, apresenta-se no contexto de suas vivências quotidianas, rotineiras ou não. Nesse sentido, por vezes, a fala sobre o lazer centrou-se diretamente naquilo que se vive (u) gerando sentimentos, emoções e sensações envolvendo prazer, satisfação de desejos, 
gostos, tranquilidade, entre outras possibilidades. Além disso, nas imagens das idosas sobre o lazer outras dimensões e aspectos da vida se fizerem presentes, em termos de oposição e limitação e/ou de complementariedade e potencialidade, como o trabalho, a família, a política, a saúde e a doença, o envelhecimento, a religião, a natureza, a alimentação e aspectos próprios da história de vida. Vejamos alguns exemplos dessas imagens-vivências-relações nas palavras das nove idosas, citadas por nomes fictícios escolhidos por elas mesmas.

[...] Saio com a minha cunhada, de vez em quando. Vamos para shopping, bater perna, para fazer fofoca, para tomar um café. [Risos] [...] (Alice, 67 anos, Florianópolis/SC).

[...] Eu adoro viajar. Eu trabalho bastante, para depois viajar. [...] Eu gosto muito de exercício. Muito, muito, muito. Muito mesmo. Cresci com isso, então é difícil não fazer, eu acho. [...] (Cris, 61 anos, Florianópolis/SC).

[...] antes eu acho que eu não tinha muito tempo também, porque eu trabalhava. Então, tu já chegas em casa de noite já cansada, tem as coisas da casa para cuidar e tudo. [...] eu acho que eu era mais parada. Hoje [...] faço bastante coisas. [...] Sou bem ativa, assim. [...] Bastante lazer. [...] (Teresinha, 60 anos, Florianópolis/SC).

[...] Os dois últimos anos de vida dele [cônjuge], a gente passou mais dentro de um hospital do que em casa. Então, ali, o lazer ficou tudo para trás. [...] Em abril desse ano vai fazer um ano [referindo-se ao falecimento de seu esposo]. Aí eu ainda estou muito parada em casa, sabe... Estou mais curtindo a casa [...] Porque uma coisa que eu nunca fiquei foi em casa. [...] Mas, ainda está sendo bom. [...] (Maria, 60 anos, São José/SC).

[...] Eu pude me aposentar, eu digo: "Eu vou ser feliz". [...] Foi naquela época que dava para aposentar por tempo determinado, entendeu? Então, eu não tinha ainda o tempo exato, mas eu pude me aposentar. Hoje não dá mais, não é?! [...] Então, é assim. A parte de lazer, especificamente do idoso, eu acho que tem muito a ver com a família, sabe... Com os amigos... [...] Tu sabes que a população brasileira está envelhecendo. Antes, quer dizer, há alguns anos, era a população adulta não idosa e a de crianças era muito maior. Agora, os velhos estão, por quê? Porque estão vivendo mais, estão tendo uma qualidade de vida, tudo. Por isso que eles querem acabar com a Previdência. Dizem que não vai passar. Vamos ver. É complicado. [...] Uma coisa que eu deixei de falar foi sobre atividade física. Eu faço atividade física! Então, é também o lazer. Ligado ao lazer: atividade física. Eu sempre faço. [...] (Diana, 73 anos, Florianópolis/SC).

[...] de lazer eu só faço cursinhos ali na escola mesmo. Aqui na escola profissional de Barreiros [São José/SC]. Faço meus cursinhos de manhã aqui. [...] Por hobby mesmo. O máximo que eu faço é para dar de presente. Faço pintura em tecido e agora estou fazendo bordado. [...] (Célia Alice, 62 anos, São José/SC). 
[...] Naquela época a gente quase não tinha [referindo-se ao lazer]. [...] No nosso tempo nem tinha aquilo. No meu tempo não tinha. No meu tempo era brincar de casinha; era, como se diz, trabalhar desde pequena [...] Quando eu era solteira, eu não perdia nada: era festa dos Passos; era no Centro; era aqui em São José [Santa Catarina]; era em Palhoça [Santa Catarina]... Trabalhava, tinha dinheiro... [...] Gostava de um carnaval... [...] Agora eu gosto de ficar sozinha. [...] Essa minha irmã mais velha dizia para mim: "Tu é que pensas, deixa tu ficares mais velha para tu veres como é ruim a solidão". Que nada! Eu gosto. Não adianta, porque eu gosto. [...] Eu fico em casa. Vendo a minha televisão. Aí fico vendo as minhas coisas: filme, novela... Eu gosto. [...] E rádio, aí eu gosto das músicas. [...] Flores, eu gosto. Gosto do quintal... Gosto de tudo. [...] a gente vai almoçar fora. Senão, é em casa. [...] Passear eu gosto. Mas, às vezes eu vou, às vezes não. Porque, também, eu sou assim: vou uma vez e depois não quero ir mais. Só se trocar de lugar. [...] Não gosto de grupo. De grupo, lá tem o São Judas. Querem me colocar. Mas, eu não vou, porque eu digo, essa coisa de ficar sentada, conversando, eu já digo que é só para falar mal da vida dos outros. Agora se fosse para fazer qualquer coisa. [...] eu gosto da ginástica. [...] Eu gosto de caminhar [...] (Rosa, 79 anos, São José/SC).

[...] E tem dias que eu não vejo ninguém. [...] Eu vou até o quintal, vou até lá, vou lá, vou lá... Só aqui. [...] Praia e eu. Eu e praia. [...] E daí também a gente se acalma. A gente não tem necessidades assim... A gente calma não tem necessidade de um prazer, um lazer. Não tem. A vida já é um lazer! [pronúncia pausada em cada palavra dessa frase]. O ser humano se quiser viver mais tem que procurar... Antigamente, os pobres moravam em morros. Hoje, são os ricos, porque eles querem se isolar do barulho e ter mais visão... Ter mais visão. Coisa mais linda, você vai ver, é você olhar para o mar... Você ouvir o mar... [diminuição na entonação de voz]. Você passar uma semana sem escutar um rádio, uma coisa assim perturbadora... Televisão, noticiário, essas coisas, eu não vejo. [...] Porque não tem mais nada para interferir na tua mente. A tua mente vai... [...] Aqui a gente não sente o tempo passar. [...] Eu converso com Deus; o mar fala comigo; o mar me diz assim: "Até que enfim, viesse me ver". Quando eu me consultava com Psiquiatra, quando eu estava meio balanceando assim, ele me disse assim: "Falou? Falou? Como é que você escutou? Escutou?”. "Ah, doutor! Eu não escutei. Está aqui ó [batendo no peito]. Falou aqui [batendo no peito]". "Ah, então tu estás bem!” [...] (Vó Jandi, 68 anos, Governador Celso Ramos/SC).

[...] Eu desisti de sair! [...] eu fui para a Psicóloga e ela disse: "Não. Tu vais dançar! Vai te divertir". E aí eu o conheci [referindo-se ao seu atual namorado] [...] É um velho chato, rabugento, mas dança que é uma beleza. Me pegou pela dança. [...] como ele é pobre, ele não quer ir a restaurante. Tenho sorte que ele é pobre [...] Então, eu vou arrumar um namorado que tem dinheiro e ele vai querer ir a restaurante. E aí? Como é que fica? [...] Ele come comigo em casa. Ele gosta de fazer também. [...] Hoje eu dei graças a Deus que tu vinhas, porque eu tenho pavor de ficar sozinha. Odeio! [...] (Justina, 70 anos, Florianópolis/SC).

As narrativas das idosas centradas em suas vivências quando se referindo ao lazer evidenciam outros "tempos" em que esse fenômeno ocorre e também relações com outras dimensões da vida. No imaginário de Vó Jandi, por exemplo, o lazer não é visto como separado da vida como um todo ou como algo supérfluo, algo que desperte um 
prazer específico. Para ela, as vivências no lazer proporcionam, principalmente, sentimentos de tranquilidade e ocorrem, inclusive, em um tempo que não é sentido como se passando.

Na sociedade contemporânea, Maffesoli (2009) ressalta que a existência de um tempo "imóvel" e o prazer de um instante eterno remetem ao nascimento de outra concepção de tempo. Um tempo que foi liberado, tornando-se ambiência, atmosfera, não sendo mais totalmente determinado por finalidades produtivas, mas sim, pela consumição em vários sentidos.

Assim, torna-se possível compreender imagens e vivências no lazer que nada devem à lógica econômica e produtivista; que têm sentido contido nelas mesmas e se relacionam aos sentimentos que despertam nas pessoas; que, ao invés de alienar, como se poderia supor, podem, na verdade, transformar, pessoas, modos de vida, contrapondo o poder do instituído e legitimado para tal, que, por vezes, não quer deixar tempo para respirar, para pensar, para nada ouvir além do mar, trazendo para essas discussões a narrativa de Vó Jandi, por exemplo.

Bruhns (1998) considera que o tempo prevalecente na sociedade contemporânea ainda é o tempo linear, contudo, aponta haver um pluralismo de tempos (físico, fisiológico, psicológico, histórico, artístico, social, individual), que não aparecem de forma unitária, mas, sim, mesclados. Desse modo, torna-se possível identificar um tempo em outro.

Esses outros tipos de tempos mostraram-se, portanto, presentes nas imagens das idosas sobre o lazer na sua vida quotidiana. Em alguns casos, excetuando-se o de Cris, que continua trabalhando, e o de Célia Alice, que nunca trabalhou, a interrupção da vida laboral a partir do advento da aposentadoria pareceu modificar imagens e vivências no lazer. Assim, características sociodemográficas específicas como constituição 
profissional, associadas às com (vivências) em tempos-espaços anteriores, mostraram-se relacionadas às imagens e vivências no lazer.

Nas imagens e vivências de Cris, entretanto, a oposição trabalho/lazer foi evidenciada pelo fato de o primeiro ainda se constituir em dimensão central em sua vida quotidiana. Isso faz lembrar as considerações de Bruhns (1998, 1999, 2004, 2009) sobre ser difícil perceber o lazer quando considerado a partir de uma relação adjetivada com um tempo específico e livre de obrigações.

Ao posicionar o lazer a partir de uma perspectiva de relação com a vida, Bruhns $(1999,2004)$ aproxima-o dos desejos humanos e das maneiras de viver, significando o lazer pelas vivências quotidianas aparentemente desimportantes, mas que indicam possibilidades de relações diferenciadas com a vida, subvertendo a lógica dominante. Centralidade subterrânea/potência social, em que os afetos e as emoções predominam, conforme o pensamento de Maffesoli (2009, 2014).

Marinho (2006) também discorre sobre vivências no lazer consideradas banais, mas que podem despertar diferentes emoções e sensações nas pessoas que as vivenciam, evidenciando algumas das relações existentes entre os seres humanos e a natureza e salientando que esta, como cenário ou como parceira, de alguma forma sempre se fez presente na vida humana, envolvendo conflitos, contradições e sensibilidades. Para Maffesoli (1998) a tendência contemporânea é de compreensão da natureza não mais como um algo a ser dominado, mas como uma parceira, com a qual convém estabelecer uma relação de reversibilidade. O autor discorre sobre natureza não apenas pela citação de aspectos do ambiente, tal qual a terra, mas se refere a ela, também, como a globalidade de cada pessoa e como o conjunto social como um todo.

Pensando sobre "natureza" com base nesses aspectos descritos por Maffesoli (1998) e Marinho (2006), foi possível compreender que a relação com a natureza se 
mostrou presente nas imagens e vivências no lazer de algumas idosas, como Vó Jandi, Justina e Rosa. Isso não apenas ao mencionarem o ambiente natural (mar, flores, etc.), mas, também, ao falarem sobre seu próprio ambiente pessoal de relações consigo mesmas e com os outros.

$\mathrm{Na}$ mesma perspectiva, banalidades quotidianas como contemplar a natureza, ouvir música, ficar em casa, e vivenciar momentos e atividades relacionadas à religião surgiram associadas às imagens relativas ao lazer. Vivências, relações e expressões sensíveis, conforme Debortoli (2012), que mostram a riqueza de processos de envolvimento com a vida no contexto das interações entre o lazer e o envelhecimento.

As vivências relacionadas ao imaginário das idosas sobre o lazer também envolveram uma multiplicidade de possibilidades de atendimento a anseios $\mathrm{e}$ preferências, relacionando-se aos percursos de vida e às maneiras de viver atuais de cada uma delas. Conforme suas narrativas, foi possível compreender que, enquanto algumas vivências estão presentes no lazer de todas elas, outras integram o lazer de apenas uma ou outra idosa. Do mesmo modo, enquanto certas vivências no lazer ocorrem diariamente, corriqueiramente, habitualmente, outras são mais esporádicas, específicas; conforme, em ambos os casos, a disponibilidade dos recursos necessários (financeiros, materiais, etc.) e a própria disposição/vontade e o interesse das idosas.

Algumas dessas vivências, sejam esporádicas ou habituais, comuns entre as nove idosas ou particulares, foram mais detalhadamente narradas por algumas dessas mulheres (Alice, Diana, Rosa, Vó Jandi), ao invés de apenas mais brevemente citadas como associadas/integrantes de seu lazer. Extraordinário. Banalidades. Narrativas que enalteceram significados e sentimentos envolvidos nas vivências no lazer.

[...] Eu tenho um grupo lá na UFSC [Universidade Federal de Santa Catarina] que a gente... Grupo de tricotar, que a gente faz "tricozinho" para a maternidade do hospital, essas coisas, para criancinhas... Eu faço para prematuros... Então, é bem... É gostoso porque a gente se reúne. É o pessoal 
que trabalhou na UFSC, então a gente relembra as coisas da vida, não é?! Da gente... Uma vez por semana. [...] (Alice, 67 anos, Florianópolis/SC).

[...] Nós paramos também na Grécia, a gente parou em um hotel. Isso em Atenas, porque a gente foi para uma Ilha com toda a família do sobrinho que é o grego. Mas, assim, em Atenas a gente ficou em um hotel onde tinha um iogurte... Coisa impressionante [aumento na entonação de voz]! Tu não vais acreditar! Tinha uma travessa com um negócio assim branco. Eu assim: "O que é isso aí?”. “É o iogurte”. "É iogurte? Não tem nada de farinha?”. "Pois não, como vai ter farinha?”. Claro. Menina, é um negócio o iogurte deles... Aí a gente ficava comendo só frutas com iogurte. Tu não imaginas. Tu não imaginas. Uma coisa, assim, impressionante. Parece um creme. [...] (Diana, 73 anos, Florianópolis/SC).

[...] Mas, tu sabes que em procissão eu não gosto de ir com ninguém mesmo. Sabes por quê? Porque a procissão é assim: eu vou lá à igreja. Entro; vou lá ao santo; saio; na hora da procissão vou acompanhar. E se tiver com uma, como uma vez que eu fui, ai que sufoco! Uma se agarrou ao meu braço. Aí tem que esperar; tem que puxar, como diz o outro. [Risos][...] Mas, eu vou. [...] E depender dos outros eu não gosto. Então, é por isso. Eu não gosto nem de depender de ninguém nem de ninguém depender de mim. Gosto de ser bem independente. [...] Encontro com elas, mas não me junto. Aí falo: "Oi”; “Oi, tudo bem?" [...] (Rosa, 79 anos, São José/SC).

[...] Eu vejo bastante filme, sabe?! Eu continuo vendo bastante. Mas, os meus filmes têm que ser todos educacionais, nada de bandidagem... Eu não gosto. Pelo papo que tu estás tendo comigo, tu já sabes. Eu gosto de filme de chef... De chef de cozinha. [...] Ah, eu vi quase todos os filmes bons, assim... Aí a Denise [filha] me chama: "Mãe, vamos ver um filmaço que vai passar. Está passando no cinema". "Como é o nome do filme?". "Já vi....". "Mãe, o filme tal...". "Já vi". Aí, às vezes, quando eu quero a companhia dela, aí eu vejo e sem querer eu solto alguma coisa. "Não pode narrar, mãe! Vai começar a narrar o filme?". Isso acontece em tudo quanto é família. [...] Estás escutando o mar? Que coisa linda! [...] Ali eu fiz uma gruta [aponta para um local na praia próxima à sua casa, que me levou para conhecer]. A primeira gruta que eu fiz. Eu peguei essas duas pedras aí e coloquei uma sagrada família no meio e a Nossa Senhora Aparecida! Tu acreditas que a fitinha da Nossa Senhora Aparecida está há quatro anos ali em cima da imagem? E tu acreditas que por trás ela está branca porque a maré comeu, mas na frente ela está perfeita? Isso aí é impressionante! Essa imagem aí é milagrosa! Ela se manifesta! Tu sabes que a Nossa Senhora da Piedade é esse lugar, não é? Olha, que bonita. Eu a pintei. Eu e o Pedro [cônjuge] a pintamos para proteger da maré. Passei um silicone nela e um esmalte. [...] Aí pode sentar aí e ficar contemplando! Olha! É gostoso. Aqui tem gente que fica o dia inteirinho na praia. $\mathrm{O}$ dia inteirinho. [momento mais prolongado de silêncio]. Eu quase não falo, mas com ele [olhando para o céu] eu falo muito. Eu falo bastante... Meu período de falar aqui na terra passou, mas com ele eu não paro. [...] (Vó Jandi, 68 anos, Governador Celso Ramos/SC).

Marinho (2006) destaca que, no quotidiano urbano, é comum emoções e sentimentos que envolvem o extraordinário serem vinculados a acontecimentos como datas comemorativas, grandes festas e eventos. Contudo, lembra-nos de que algumas banalidades da vida, como escutar o canto dos pássaros, sentir o cheio das plantas, 
conhecer outras pessoas e paisagens, estar na natureza, entre outras possibilidades dessas "coisas simples da vida" podem fazer as pessoas vivenciarem emoções e sentimentos tão prazerosos quanto os "grandes" fatos podem fazer. É como se nelas, ainda conforme Marinho (2006), não fosse preciso justificar nem entender os sentimentos, mas sim, simplesmente, vivê-los.

Isso parece se aproximar, relativamente, de todo o encantamento de Diana ao contar sobre um iogurte que saboreou em uma de suas viagens internacionais, as quais costumam eventualmente integrar seu lazer, conforme sua narrativa, mas que foram destacadas principalmente pelas relações estabelecidas com o alimento. Da menção de Alice sobre o estar junto, como pano de fundo e, ao mesmo tempo de relevo, contido nas vivências semanais no contexto de um grupo com finalidades (aparentemente) específicas, mas em que o que se destaca é o compartilhamento de sentimentos, afetos, lembranças com outros da mesma “tribo", lembrando a metáfora de Maffesoli (2009). De todo o deslumbre de Vó Jandi ao se remeter aos seus momentos de contemplação da natureza e de relação com a religião, assim como ao seu detalhamento sobre uma vivência no lazer que ela considera "comum" de qualquer família, mas que traz à tona todo o componente sensível envolvido ao não apenas atender o gosto da idosa por assistir a filmes, mas também, por possibilitar que ela tenha a companhia de sua filha. Além disso, do destaque desta idosa ao gosto por programas televisivos relacionados à culinária, mostrando como uma banalidade quotidiana envolvendo a alimentação é inerente ao lazer dessa idosa e vice-versa, como também verificado no contexto de outras narrativas. Aspecto notadamente destacado, assim, entre idosas com doença celíaca.

Araújo et al. (2010), ao discutirem aspectos sobre doença celíaca, hábitos alimentares e qualidade de vida, consideram ser preciso direcionar atenção para o fato 
de que a alimentação de cada pessoa precisa ser compreendida como integrada à sociedade. Sociedade essa que, com base nas narrativas exemplificadas pelas idosas, envolve diferentes dimensões e aspectos da vida quotidiana que se relacionam à alimentação, também quando se referindo ao lazer.

Dimensões e aspectos envolvendo religião, contemplação e ficar sozinho fazem lembrar de considerações descritas por Maffesoli (2019). O autor enaltece a difusão do divino na vida quotidiana e da manifestação de entusiasmo que ele pode ocasionar. Salienta que a busca pelo silêncio leva a uma força do pensamento, cujo dinamismo é possível reconhecer em diferentes esferas. Ressalta que, algumas vezes, é preciso uma linguagem silenciosa para celebrar a palavra de Deus. Linguagem que envolve a natureza, a imensidão, a obscuridade da terra que não deixa de sustentar a vida. Algo extraordinário, que possui eficácia própria e, em decorrência disso, configura-se como "falante".

É assim que o autor considera que o sacramento torna visível uma força invisível. Que prevalecem momentos particulares, com formas de admiração, contemplação, de um silêncio que fala. A importância que o catolicismo confere às figuras emblemáticas representadas pelos santos acentuam o aspecto místico da tradição. Enfim, possibilidades que reiteram que a razão só é legítima se for sensível (MAFFESOLI, 2019), e, inclusive, colaboram para compreender diferentes imagens e vivências sobre o lazer.

Assim, entre as banalidades identificadas no lazer que, igualmente, atendem a desejos, envolvem sentimentos e preferências humanas, é possível incluir, também e paradoxalmente, o desejo de sair sozinha, de sentir-se independente, ainda que no contexto de uma festa religiosa que ocorre em meio a muitas pessoas, como detalhado sobre uma vivência no lazer de Rosa. Em outras palavras, a individualidade no contexto 
da coletividade. Essa idosa afirmou gostar de ficar consigo mesma e/ou em sua própria casa, fazendo atividades que gosta. Mas, também, falou sobre gostar de se movimentar, de passear, de não ficar parada.

Isso permite relativizações com a noção de nomadismo presente nos escritos de Maffesoli (2001); ou seja: a consideração das dinâmicas de deslocamentos e de pausas, de buscas por sensações de liberdade e de segurança no contexto do lar, que, conforme Marinho (2006), podem ser observadas em determinadas vivências no lazer - atividades de aventura na natureza -, no contexto da pesquisa dessa autora; passeios e viagens no âmbito do presente estudo.

Nas reflexões apresentadas por Debortoli (2012), o autor questiona por que algumas pessoas não poderiam viver de forma mais lenta, silenciosa, com mais contemplação. Tomando o devido cuidado de não simplificar as relações, pois processos de solidão podem estar associados a situações de adoecimento, esse pesquisador ressalta que ficar sozinho também faz parte dos processos de elaboração de nós mesmos. Precisamos do outro, mas também de nós mesmos; percebendo, sentindo, usufruindo e confrontando a nós mesmos com tudo o que temos de bom e, também, de "sombrio".

Conforme Britto da Motta (2018), a solidão, na qualidade de um sentimento, pode estar presente em qualquer idade, podendo significar desconexão e insatisfação emocional de uma pessoa em relação a outras, em situações e circunstâncias que não atingiriam outras pessoas. Pode ser percebida tanto quando há poucas pessoas presentes na vida diária, como também quando as pessoas com que se convive não estabelecem mais significados na vida da outra. No caso específico da velhice, a autora salienta que a solidão adquire configuração especial, pois remete a convivências passadas da história de vida, podendo revelar perdas, ou ganhos inexpressivos. 
Parece ser necessário relativizações a cada contexto de vida, quando se tratando de pessoas idosas. Para Rosa, por exemplo, ficar sozinha foi algo destacado entre suas preferências no contexto das vivências no lazer. A solidão não foi vista por ela como algo ruim para sua vida. Para Justina, por outro lado, ficar sozinha em casa foi visto como algo pavoroso, sendo a solidão associada a sentimentos negativos.

Aguiar (2009), considera, em outra perspectiva, que, mesmo nas vivências no lazer marcadas por um importante componente individual, é mantida uma essência coletiva, a qual se faz presente pela existência de outro que não necessariamente é uma pessoa. Outro que pode ser uma música, um mundo no pensamento, entre outras possibilidades, que, em suma, evidenciam que, para a compreensão do lazer no cenário pós-moderno, uma postura relativista torna-se indispensável.

Além das (e incluindo as) as vivências supracitadas, de forma ampliada, as idosas apresentaram como suas vivências no lazer muito do próprio quotidiano. Tais vivências foram apresentadas em narrativas como as exemplificadas a seguir.

[...] Eu adoro dirigir! [...] Adoro. [fala pausada em cada sílaba desta palavra]. Muito bom! O dia que o DETRAN [Departamento Estadual de Trânsito] não me renovar a carteira eu estou ralada. [Risos] [...] Não viajo tanto por causa dele [apontando para Flash]... Do gato... Senão, eu não parava aqui. [pausa na fala]. Ele não suporta entrar no carro. Se ele está no carro e eu ligo o carro, ele sai, fica alucinado. [...] (Alice, 67 anos, Florianópolis/SC).

[...] Eu gosto de viajar. [...] Eu tenho uma filha que mora na Austrália e outra que mora nos Estados Unidos. Então, vira e mexe eu vou para lá. Tenho o meu afilhado, esse filho da minha irmã, que passou para Rio Branco [Acre], para ser diplomata. Então, a cada quatro anos ele mora em uma cidade. Ele estava em Roma e eu fui a Roma. Agora ele está em Myanmar e eu quero ir a Myanmar. No Japão, eu não consegui ir. Mas, sempre no lugar que ele está eu tento ir para conhecer também. [...] Vou para o Rio de Janeiro... [...] (Cris, 61 anos, Florianópolis/SC).

[...] Eu sempre gostei de caminhar. [...] Faço musculação, caminho, pedalo... [...] E amo. Amo. O dia que eu não faço nada parece que fica faltando aquilo ali no meu dia. [...] nós fomos para Salvador [Bahia], em novembro. [...] Eu vou para o hotel e lá a gente faz alguns passeios. [...] (Teresinha, 60 anos, Florianópolis/SC).

[...] Eu sou muito preguiçosa de sair de casa. [...] Uma coisa que eu faço, que eu gosto, é de caminhar. [...] (Maria, 60 anos, São José/SC). 
[...] Bom, aí o que acontece hoje na parte de lazer, isso do meu lado: a família, a maioria é celíaco. [...] As nossas festas costumam não ter nada de glúten. [...] Quando é uma festa, assim, de amigos, eu não deixo de ir. [...] Eu sempre fiz na vida atividade física. [...] agora eu faço Pilates três vezes por semana. [....] faço isso e gosto muito. Isso também faz parte do lazer do idoso. Fazer, dançar... alguma atividade física, entendeu?! Eu acho que é muito bom. [...] Todos os domingos a gente reúne os meus filhos casados; a gente reúne as noras, os genros... Vem todo mundo para cá. Eu sempre faço um prato, um domingo sim, um domingo não. Eu faço um prato sem glúten, alguma coisa assim tipo peixe com risoto de frutos do mar, coisas assim... Ou, enfim, tem vários cardápios, vários pratos que eu faço. Aí no outro domingo, então é churrasco, o meu marido ou o meu genro fazem churrasco. Tudo coisas sem glúten. [...] Nós fizemos já, eu acho que umas duas vezes, uma, não me lembro... O café colonial em uma casa de idosos lá de São José [Santa Catarina]. [...] (Diana, 73 anos, Florianópolis/SC).

[...] Na semana passada, no sábado, ganhamos a janta ali no [restaurante] "Barriga Verde". Fazia tempo que a gente não ia ali. [...] Às vezes, quando tem festa, assim [...] De família, de amigas. [...] Na frente da nossa casa tem um barzinho. Eles descem para tomar cervejinha ali e eu desço com a minha. Levo a minha em um "isoporzinho". Aí a guria guarda na geladeira e eu só vou pegando. [...] Esses dias fizemos um churrasco lá na praia [...] Eu mesma não deixo de ir. Faço a marmita e levo. [...] (Célia Alice, 62 anos, São José/SC).

[...] Então, há oito anos já estou aqui [espaço público de atividades para idosos]. Era dança e ginástica. [...] Eu gosto de caminhar. [...] Ah, e pintar... Ontem, ainda pintei lá a frente da minha casa, aquele meio fio... Amarelo lá... [...] Depois, o muro lá estava muito feio. Fui lá e dei uma lavada, para depois dar um banho, dar uma pintura também. [...] Essas coisas assim eu gosto de fazer. Agora, se for para ficar sentada, não. Não me convida. Ainda se fosse lá que elas fossem dançar... Não gosto de bingo. Até que brinco, mas não gosto. Gosto de dominó. Mas, também quando eu saio dali que me levanto estou toda quebrada. Porque aí é muito tempo sentada... Eu não posso ficar muito tempo sentada. [...] Assim, andar nos lugares eu gosto de ir. [...] nós estivemos lá na polícia montada, tudo... a gente foi àquelas coisas lá de planta. Tudo isso. [...] Tenho as minhas plantinhas. Tenho flor, tenho tudo. Tem uma tira e aí ali é que tem meus pezinhos de pimenta. [...] Gosto de ver filme. Aí eu fico vendo filme. E quando assim, às vezes, a gente vai almoçar fora, quando tem um aniversário; ou, às vezes tem uma festa em algum lugar, ela convida, a filha. [...] já viajei muito... [...] Eu venho caminhar com a filha aqui, mas ela vai e eu vou atrás. Mas, ela tem que esperar eu fazer uma hora. Ela para e fica me esperando. [...] Um baile, para mim, é o divertimento melhor que tem. [...] Não sou de sair de casa. Gosto da companhia [...], assim, de estar aqui, conversa, vai embora... [...] Não gosto de ir à casa de ninguém. Nem em parente. Eu só gosto de ir quando está no hospital. Eu só vou em casa se for uma necessidade. Não gosto. Sei lá, eu vou à minha irmã e enquanto eu não saio, não vou embora, não fico descansada. Não gosto de ir. Sei lá. [...] Quando eu inventava de ir a um lugar, ainda hoje, se me disser assim: "Ah, vai ter tal coisa lá em São José". Eu digo "Ah...", aí eu me arrumo e já vou lá ver. Eu venho sozinha, entendes? [...] Vou sozinha. Não gosto de ir com ninguém. [...] eu tenho televisão na cozinha. Estou fazendo as coisas e vendo as coisas. Senão, é meu rádio ligado. Gosto. Gosto mais do que a televisão, assim não sendo filme, essas coisas. O que eu gosto de televisão é filme e novela. [...] Ah, adoro escutar música. [...] (Rosa, 79 anos, São José/SC).

[...] Eu faço parte de um movimento de casais: "Shalom". É um movimento bem grande. Tem muitos eventos. [...] A maioria dos movimentos de casais 
que nós nos comunicamos sempre é idoso. Os casais dos nosso tempo ainda estão tudo lá. [...] Onde eu me divirto é na praia, durante o dia, quando estou bem; e na igreja, à noite, quando tem algum evento, alguma coisa, aí eu canto... Nós cantamos. [...] Eu gosto [de cozinhar]. Eu gosto de fazer bem [ênfase] feitinho. [...] Eu converso com os cachorros lá da primeira vizinha de lá; eu converso com o cachorro lá do vizinho da outra rua; eu sei que é ele. [...] invento aquelas coisas de plantar... [...] Mas, a casa é grande. Vou aqui, vou ali, vou lá, vou lá... [...] Tenho um bugue lá em cima. [...] Tenho a mesa de sinuca... [...] Tamanho profissional! É bem boa de jogar. Fogão a lenha. No inverno para fazer quentão, pinhão... [...] Às vezes, eu fico vendo filmes... [...] No verão eles [netos] vêm. E quando vem, vêm todos. A família do "bicudo": quando vem um, vem tudo. Aí tem uma mesa de sinuca ali atrás para eles se entreterem. Outros ficam vendo "Sky" [empresa de serviços de telecomunicação] lá em cima. [...] Os pescadores estão lá. Estão jogando a rede. Na tainha. Às vezes, eu fico o dia todo lá com eles. A gente brinca, conta piada... Conheço cada um deles... Eles queriam todos entrar no grupo [do WhatsApp]. Mas, é muita gente. [...] Eu tenho um grupo daqui, um grupo dos Ganchos [Governador Celso Ramos/SC], um grupo de Barreiros... [São José/SC] [...] Aqui nós somos o grupo do canto. O pessoal que canta e o pessoal que cuida da igreja. É um grupinho pequeno aqui. Deve ter umas 20 e poucas pessoas só. Mas, lá embaixo tem 200. [...] Aí eu fico só no celular. Eu tenho um tablet ali, mas nem aciono. Tenho um computador ali para as crianças quando vierem aqui ligarem o computador. [...] Nós temos nosso clube de subtenentes e sargentos ali na coisa... Ali nós vamos fazer o aniversário da filha do Jeferson [filho]. [...] quando não dá praia, dá clube. [...] O "Água de Palmas" [clube] tem tudo. Tem tudo, tudo, tudo. [...] Tem águas de inverno e águas de verão. Tem dez piscinas de adulto para o verão. É porque quando tem muita gente em uma piscina, a gente tem opção. Aqui tem muita gente, tem jovem, vou para outra. É engraçado que cada piscina tem uma idade sabe? É ali em Palmas [Governador Celso Ramos/SC]. Eu e meu marido vamos só uma vez por semana [...] Tem jogos, tem dança... Depois do banho a gente pode ficar para dançar o baile. Tem baile. Tem um salão arrumado. A gente pode dar opinião no salão. "Dá uma opinião aqui. $\mathrm{O}$ que nós vamos fazer para enfeitar isso aqui?". Ah, festa junina então tem quase todo o mês de junho. [...] A gente vai à ilha de Anhatomirim quase assim... A gente aluga... A gente combina com uma turminha. A gente paga a passagem, claro. É igual quando você quer se encontrar no restaurante, cada um paga a sua. Mas, o fato de a gente estar tudo junto ali já é uma coisa boa. A gente junta um grupo e aluga a embarcação. Se tiver 16 pessoas, ele já vai. Aí a gente faz conforme a turma quer. [...] fui a Fernando de Noronha [Pernambuco][...] Mas, eu não troco isso aqui por lá. Porque lá tem muita vigilância. [...] E você tem um tempo determinado para ficar lá dentro. [...] E as pessoas que moram lá não têm segurança de terreno. Não é nada delas. Elas compram, mas depois se elas não cuidarem, se fizerem qualquer coisa errada, vão embora. Então, é uma tensão, sabe? É um lugar tenso. Não é como nós: “Ah, isso aqui era do meu avô, da minha avó...”. Não, aquilo lá não. [...] (Vó Jandi, 68 anos, Governador Celso Ramos/SC).

[...] A minha mãe era assim bem "atiradona" para fazer as coisas. E a minha mãe gostava também de cozinhar. Eu acho que me acostumei com ela. A minha avó também. [...] quem gosta de se cuidar tem que gostar de cozinhar. [...] Lá na lagoa, na "SAL" [Sociedade Amigos da Lagoa]; lá no "Brand" [centro de eventos], no Estreito [Florianópolis/SC]. É muito bom lá. [Clube] Maré Alta... [...] No início eu ia com a minha empregada; ia com a filha dela... Aí depois eu comecei a ir com ele [atual namorado]. [...] Ele diz que eu estou pesada para dançar. [...] Esse domingo a gente não foi. Ah, faz uma falta... Porque a gente se mexe... Outra coisa que ele faz de bom para mim é jogar comigo. A gente joga pife, dama, burro e dominó. Se a gente está cansado de ver filme, vamos jogar; se estamos cansados de jogar, vamos ver filme. É uma beleza. [...] Eu tenho uma amiga que é cega. [...] E tem essa 
agora que eu fiz amizade aqui, que eu apresentei as duas e elas ficaram amicíssimas. [...] Eu fiquei tão feliz, porque se eu não posso mais dar tanta atenção para a minha amiga cega, como eu dava quando eu morava lá, e por causa do namorado, então, pelo menos elas são amigas, saem juntas. [...] Tem uma que, às vezes, faz Pilates ali comigo. E a gente se vê muito pouco. Aí eu faço Pilates[...] Faço três vezes por semana, meu amor. [...] Eu chamo a minha manicure para tomar café. Eu faço bolo e digo: "Olha, tem bolo. Vamos lá tomar café”. Ah, vamos lá. Dou planta para todo mundo [...] Adoro. Olha aqui as minhas plantinhas que coisas lindas. [...] Eu vou lá visitar a minha amiga. Faz um século que eu não vou a casa dela. Elas estão tudo com ciúmes do Alexandre [atual namorado] [...] (Justina, 70 anos, Florianópolis/SC).

Algumas idosas também se reportaram a vivências que deixaram de integrar o seu lazer, especialmente em decorrência da própria condição de tratamento da doença celíaca e/ou de outros aspectos associados ao processo de envelhecimento. Mas, em alguns casos, trataram-se simplesmente de vivências de outras épocas de sua vida.

Conforme Nitschke (2007), as pessoas agem segundo sua própria compreensão, a partir das imagens, dos seus símbolos, do seu "mundo imaginal", o qual foi sendo construído em seu processo de interação com o mundo. Debortoli (2012) salienta que as vivências no lazer se relacionam com os diferentes tempos da vida, correspondendo essencialmente ao percurso de viver, que é entendido pelo autor como sendo uma jornada de desenvolvimento, de sabedoria e de formação de habilidades relacionadas à vida. Jornada que é, sobretudo, quotidiana e, também, relacional. Isso não diminui a importância das reflexões sobre as maneiras que as pessoas se constituem como histórias de legitimidade, valor, dignidade, integridade.

[...] Não tenho mais ânimo também, de sair à noite, essas coisas... Dez, dez e meia, eu já estou morrendo de sono, eu quero é dormir [...] [Risos]. Quem quiser vai para carnaval, para isso, para aquilo. Eu fico na minha. [...] Às vezes, eu quero sair para dar uma caminhada na praia, aí vou um pedacinho e não dá. Aí eu volto. Às vezes, eu acho que é frescura minha, ou, não sei se é falta de vontade, mas... É 24 horas a dor. [...] (Alice, 67 anos, Florianópolis/SC).

[...] Eu evito comer fora. Isso foi uma coisa que eu evitei. [...] Eu sinto que, às vezes, é meio chato. [...] Aí os programas são mais em casa. [...] eu mesma cozinho. [...] Final de semana também. [...] Estou sempre inventando coisas em casa para fazer. [...] (Cris, 61 anos, Florianópolis/SC). 
[...] às vezes, assim, eu prefiro não ir aos lugares. [...] tem gente, que por incrível que pareça, não sabe o que é o glúten. [...] Sabe, falta um pouco de conhecimento ainda do que é o glúten, o que contém glúten... As pessoas não sabem ainda, não é?! [...] (Teresinha, 60 anos, Florianópolis/SC).

[...] ultimamente não estou fazendo [referindo-se às caminhadas]. Muito calor, sabe. Sol muito quente, durante a noite é perigoso, durante o dia muito quente, então estou bem parada. E eu preciso caminhar. [...] A gente ia a um churrasco, na casa da família do meu marido, que daí da parte dele eles não têm problema [referindo-se à doença celíaca]. [...] Aí tem o irmão dele, também, que a gente ia muito lá. [...] Essa parte aí mudou, de a gente almoçar fora. $\mathrm{Ou}$, às vezes, um faz aniversário: "Ah, vamos comemorar, vamos comer uma pizza”. Não tem mais... Não dá. [...] Porque não dá para a gente ir. Tudo quanto é lugar é lanche. [...] (Maria, 60 anos, São José/SC).

[...] Então, agora eu passei para o Pilates, porque surgiu uma fibromialgia também. [...] Aí eu tive que sair da academia. [...] Fazia musculação e até o médico achou estranho: "Como? Tu não és sedentária, nem nada". Caminhava muito... [...] Todos os dias musculação. Não era assim, duas ou três vezes na semana. Como eu já estava aposentada, então eu ia a pé... Olha só o que eu fazia, eu era louca eu acho: eu ia a pé até a academia, que era perto daqui. Agora não tem mais. No final dessa rua aqui. E depois ainda ia caminhar uma hora. Eu não sei como eu tinha ânimo para fazer isso. Fazia sozinha. Foi aí que eu comecei a perceber, por exemplo, que quando eu estava voltando para casa, eu tinha que sentar na calçada. Foi aí que eu descobri a hipoglicemia. [...] Vou a pé até a academia. Mas, enchi o saco de caminhar. Não caminho mais. [...] (Diana, 73 anos, Florianópolis/SC).

[...] Fazia Pilates. Já estou com vontade de voltar, porque as juntas já estão começando a querer enferrujar. [...] Eu parei porque fui fazer a cirurgia da vista, de catarata. Aí pagar e ficar parada, não. Aí acabei ficando com preguiça de voltar. Mas, eu vou voltar. [...] (Célia Alice, 62 anos, São José/SC).

[...] não gosto mais assim de andar com turma, com isso, com aquilo... [...] À Aparecida eu ia todo ano. São Benedito... À Festa da Aparecida. Agora ia ter. Até a mulher já ligou para mim. Eu digo: "Não, agora eu não vou não". Mas, ah, já viajei muito... Já fui ao Pai Eterno duas vezes, lá em Goiás. Em Brasília... Lá para o Rio Grande, tudo... Agora, pois é, eu já estou mais assim por causa de escutar, pode dar qualquer coisa, já estou mais velha, não quero dar trabalho para estranho. "Ah, nós cuidamos da senhora, não sei o quê". Eu digo: "Não, mas eu não gosto de depender de ninguém". Porque eu ia à Aparecida e andava aquilo tudo lá sozinha. Agora, depender de gente, atrapalhar, porque aí a pessoa anda rápido, agora eu já não ando tão rápido. [...] Agora só vou a [festa] do Centro: a do Senhor dos Passos. [...] Agora tem aqueles andarilhos lá na cidade... [...] (Rosa, 79 anos, São José/SC).

[...] Tinha amigas que vinham de São Paulo e ficavam ali [local próximo à residência da idosa]. Aqui era tudo um mato só. Era uma trilha. Aí nós a trazíamos, porque ela estava sozinha. Aí nós a trazíamos para casa. Vinha eu, a Denise [filha], todo mundo que estava aí, as pessoas que estavam comigo. Depois a turma daqui ia nos levar para casa. Aí chegava lá e a turma de lá vinha trazer eles para casa. Em um instantinho fizeram a trilha. [...] Aquela casa ali [aponta para uma casa próxima à sua] era de um amigo nosso. Nós íamos para a praia e ele ficava fazendo macarrão. E ele de noite trazia um gaiteiro. Todo mundo trazia um pedaço de carne, qualquer coisa para assar ali... Nós ficávamos tocando gaita, jogando baralho. Era uma folia! Quando a gente veio para cá isso aqui era divertido, porque a gente era novo. A gente fazia festa mesmo. Agora a gente que quer sossego. A gente mesmo. E os 
novos de hoje não sabem como é ser divertido como nós éramos. [Risos] [...] (Vó Jandi, 68 anos, Governador Celso Ramos/SC).

[...] Antes, eu acreditava que podia viajar; eu acreditava que podia ir a um restaurante [...] A contaminação cruzada, para mim, não [ênfase] dá. [...] E a gente sofre bullying das pessoas [...] Eu não leio mais. Tenho uma preguiça mental absurda. Não sei o que é isso. E eu não tenho vontade. Eu acho que é a "depre" [depressão] que pega. [...] (Justina, 70 anos, Florianópolis/SC).

É possível observar, ainda, que as falas sobre esses tipos de vivências que não se mostram mais no lazer das idosas também envolveram relações com ânimos, desejos, (des) gostos, processos emocionais e afetivos, reiterando como esses aspectos "não racionais" integram as imagens sobre o lazer e as vivências nesse âmbito. Assim, foi possível compreender que as preferências no lazer podem ser modificadas, diante de mudanças outras na própria vida (doença, envelhecimento, etc.), ou mesmo porque, de alguma forma, perderam o sentido, enquanto outras vivências pareceram adquirir mais significado.

Maffesoli (2009) salienta que o procedimento intelectual atento aos aspectos sensíveis se pauta na lógica do vivido e na sua dinamicidade orgânica. Assim, as compreensões também sobre as vivências que deixaram de integrar o lazer das idosas reforçam toda a dimensão sensível presente no lazer.

Nas narrativas de algumas idosas também foram apresentadas vivências desejadas, que não integram seus momentos no lazer, mas que as interessam de algum modo. Algumas não são vivenciadas pelos próprios limites relacionados ao tratamento da doença celíaca que repercutem nas vivências no lazer, como as dificuldades de se alimentar em lugares externos ao ambiente doméstico. Mas, outras, envolveram outros limites, como falta de oportunidades para acessá-las, por exemplo.

[...] Eu gostaria de fazer a hidroginástica... [...] Eu tentei fazer curso de artesanato também, na madeira, mas gasta muito [...] fica acumulando aquela "coisarada". Eu aprendi, até, a fazer. E depois, também, pelo Youtube a gente aprende muito isso. Era só mais, assim, pela saída, de conhecer as pessoas... Pode ser que eu ainda volte a fazer, sabe... [...] Vai ter um segundo encontro [alusivo à doença celíaca]. O primeiro eu não fui, mas quero ver se vou 
nesse agora. [...] eu não fui porque meu marido estava no hospital [...] Mas, nesse aí eu quero ir. Já convidei as minhas irmãs, a minha sobrinha, para a gente ir. Não é? Legal... Quero comer um monte. [...] Uma coisa que eu não consegui conquistar foi dirigir. Me faz uma falta doida. [...] Mas, não consegui. De medo. [...] Tenho vontade. Tenho pesar de não encarar, de não saber. Tenho uma frustração mesmo de não saber. Senão eu ia a muito lugar, nossa. Estava passeando. Não ia parar em casa. [...] (Maria, 60 anos, São José/SC).

[...] Inclusive, eu achei interessante que a minha irmã que é aposentada também, da Química, ela tem um grupo, que é da UFRGS [Universidade Federal do Rio Grande do Sul] eu acho, que é "envelhecença" o nome... "Envelhecença". Mas, é um negócio maravilhoso. É assim: trocam dicas de livros; comentam livros; eles pegam livros e aí a pessoa que leu fala sobre o livro; sobre filmes... É muito legal. Então, é um grupo intelectual de idosos. $\mathrm{Eu}$ achei muito bom, muito interessante. Eu não conheço nenhum na UFSC, mas se tiver, eu acho assim bem interessante. [...] (Diana, 73 anos, Florianópolis/SC).

[...] Eu queria fazer mais coisas. [...] Gostaria de ir lá ver a minha filha [que mora no Canadá] e essa coisa toda. Eles acham que eu não vou porque eu não quero. E a gente sabe que não é assim. [...] (Justina, 70 anos, Florianópolis/SC).

Debortoli (2012, p. 17) enfatizou "a poesia de estarmos vivos", envolvidos com um mundo plural e que está em constante movimento, transformando-nos a cada dia e demandando-nos cuidado, atenção, sensibilidade, percepção, ação. Em suma: sabedoria para a ampliação de nossas aprendizagens e formas de participação. $\mathrm{O}$ autor considera como um dos sentidos interessantes do lazer a sua visualização por meio de experiências que possibilitam conhecer, viver e ampliar os potenciais da vida humana.

As vivências no lazer das idosas com doença celíaca entrevistadas nessa pesquisa superficialmente não se diferem em demasia de vivências no lazer de idosos sem esta doença, conforme resultados apresentados por outros estudos nacionais (COUTINHO; ACOSTA, 2009; SANTOS, 2015). Em todos os casos, há, por exemplo, vivências com familiares, com amigos, passeios, viagens, atividades físicas, ficar em casa, participar ou não de grupos, entre outras possibilidades. Contudo, profundamente, diferenças importantes tornam-se visíveis, especialmente, considerando-se as limitações trazidas pelo tratamento necessário à doença celíaca, que atingem principalmente vivências sociais no lazer, vivências com a família, com amigos. 
As possibilidades de vivências no lazer relatadas pelas idosas, em suma, mostram todo o "sensível" envolvido no lazer, como dimensão da vida quotidiana; aproximando-se das reflexões de Debortoli (2012) sobre as diferentes formas de vivenciar o processo de envelhecimento, especificamente a partir do olhar sobre o lazer. Enquanto alguns idosos preferem a intimidade de suas vidas, o contexto de suas residências, outros querem sair e se relacionar. Enquanto alguns não querem participar de grupos, outros querem conhecer novas pessoas e lugares, praticar atividades físicas, entre tantas outras possibilidades. Segundo o autor: “[...] nas miudezas da vida há uma riqueza de possibilidades infinitas de relação” (DEBORTOLI, 2012, p. 23-24).

São, justamente, essas riquezas, diversidades, relações, relativizações que enfatizamos ser preciso (re) conhecer, pois, ainda que algumas vivências no lazer possam ser aparentemente "comuns" entre idosos com e sem doença celíaca; de um e de outro local; entre homens e mulheres, são as miudezas que as diferem; as maneiras como são vividas e significadas; os limites e as potências envolvidos.

Profissionais da saúde, e aqui destacamos especialmente os da área da Educação Física, ao direcionarem o olhar para essas profundezas, podem vislumbrar possibilidades de atuação e de cuidado, que, por exemplo, possibilitem ou vislumbrem caminhos para que vivências no lazer desejadas possam se tornar realidade; para que vivências restringidas possam se tornar acessíveis; ou mesmo para que as vivências existentes sejam legitimidades, devidamente (re) conhecidas em suas (des) importâncias.

Tudo isso parece perpassar pela necessidade de mais informações sobre a doença celíaca; de conhecimento e, também, sensibilização sobre o assunto. Restrições diversas relacionadas ao lazer, por exemplo, poderiam ser aprofundadas em cursos de formação inicial e de capacitação profissional na área da Educação Física. Isso, contudo, não é 
suficiente. Ter acesso a pessoas com doenças crônicas que convivem com tratamentos que demandam algum tipo de restrição que alcance o lazer, também se mostra como necessário. Teorias. Práticas. Razões. Sensibilidades.

\section{Considerações Finais}

Nesta pesquisa o lazer foi apresentado pelas idosas com doença celíaca como sendo vivido e sentido por meio de diferentes possibilidades, mas que, em suma, envolvem sensações de satisfações de desejos, gostos, preferências, tranquilidade, felicidade. As imagens que transitam no imaginário dessas mulheres colocam o lazer ora ocorrendo em tempos outros, libertos de obrigações e de cronômetros; ora relacionando-se de forma oposta a dimensões da vida como o trabalho, sendo menos frequente a percepção de manifestação do lazer neste caso.

A relação com a vida produtiva mostrou-se imbricada, portanto, em formas de ver e de vivenciar o lazer na vida quotidiana atual. Relações também apresentadas em referência ao processo de envelhecimento humano, à política, à religião, à natureza, à saúde, à doença, à alimentação. Todo complexo relacionado ao lazer, que pode ter sentido por si só e nada dever a outras dimensões da vida, mas que delas parece não poder integralmente se desconectar.

"Todo" que envolveu vivências extraordinariamente banais, incluindo: cozinhar; plantar; cuidar da família, da natureza, da casa e dos animais; curtir a casa; cantar; ouvir músicas; assistir a filmes, a novelas e a outros programas televisivos; participar de grupos (comunitários, religiosos, com finalidades filantrópicas, de atividades manuais, de casais...); sair para comer e/ou ficar em casa com familiares e/ou com amigos; participar de festas/encontros com amigos e/ou familiares; participar de festas religiosas; sair para dançar; praticar atividades físicas (caminhar, pedalar, ginástica, 
Pilates, musculação...); passear e viajar (destinos nacionais e/ou internacionais); dirigir; ir ao shopping center; ir a clubes; ir à praia; ir à igreja; contemplar a natureza; conversar com Deus; conversar por meio de aplicativos de mensagens no celular; jogar (dominó, cartas, sinuca...). Em suma, muito do próprio quotidiano. Muito do que a vida, em suas histórias de dificuldades, (in) oportunidades, e circunstâncias, permitiu.

Assim, ao falarem sobre lazer, as idosas também se remeteram a vivências que deixaram de integrá-lo, por simplesmente terem perdido o sentido, por novos interesses e gostos terem surgido ou terem sido modificados, mas, também, por limites relacionados ao tratamento da doença celíaca e/ou a aspectos relacionados ao envelhecimento, como a convivência com dores e dificuldades na mobilidade. Alguns desses limites também foram relacionados a vivências desejadas, mas não vivenciadas. Estas, em outros casos, são limitadas por falta de oportunidades para acesso. Tudo isso indicando a relação das vivências e das imagens sobre o lazer com os desejos, as necessidades, os sentimentos, os gostos... Aspectos sensíveis atrelados à razão.

Poder vivenciar as diferentes possibilidades existentes no lazer é um direito de todos. Ter direito à alimentação também é primordial para a vida, e não apenas alimentação no sentido de nutrir o corpo em vista de demandas energéticas ou de atendimento a restrições alimentares específicas, mas, também, na perspectiva de nutrir a alma e a vida em sua multiplicidade de relações, especialmente, neste caso, com o lazer.

As vivências apresentadas nessa pesquisa como integrantes (ou não) do lazer das idosas com doença celíaca, bem como suas imagens sobre o fenômeno lazer podem servir como ponto de partida para aguçar o interesse por esse tipo de compreensão; ou mesmo, para, simplesmente, fazer considerar a existência de todos esses parâmetros sensíveis, pessoais, coletivos, banais e extraordinários que podem se associar ao lazer de 
pessoas idosas com doença celíaca, implicando necessidade de consideração em qualquer tipo de iniciativa profissional com essas pessoas (e não apenas para elas ou

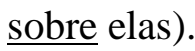

Assim, são abertos espaços para a realização de estudos similares que possam avançar em algumas das limitações apresentadas por este, como a identificação de apenas pessoas do sexo feminino para o desenvolvimento da pesquisa e a realização de um único encontro com cada participante para a entrevista. Outras pesquisas podem colaborar para o desenvolvimento de compreensões sobre o quotidiano de idosos com doença celíaca, com foco em suas vivências no lazer e em suas imagens sobre esse fenômeno.

\section{REFERÊNCIAS}

AGUIAR, A. L. V. Lazer: reflexões a partir da sociologia dos afetos de Michel Maffesoli. 2009. Trabalho de Conclusão de Curso (Graduação em Tecnologia em Lazer e Qualidade de Vida) - Instituto Federal de Educação, Ciência e Tecnologia do Rio Grande do Norte, Rio Grande do Norte, 2009.

ALMEIDA, L. M. Prevalência de doença celíaca entre usuários idosos do laboratório de patologia clínica do hospital universitário de Brasília. 2012. $78 \mathrm{f}$. Dissertação (Mestrado em Ciências Médicas) - Faculdade de Medicina, Programa de Pós-Graduação em Ciências Médicas, Universidade de Brasília, Brasília, 2012.

ARAÚJO, H. M. C. et al. Doença celíaca, hábitos e práticas alimentares e qualidade de vida. Revista de Nutrição, Campinas, v. 23, n. 3, p. 467-474, jun. 2010. Disponível em: http://www.scielo.br/pdf/rn/v23n3/14.pdf. Acesso em: 05 set. 2017.

BERNARD, H. R. Research methods in anthropology: qualitative and quantitative approaches. 4. ed. Lanham: Altamira Press, 2006.

BRASIL. Portaria n. ${ }^{\circ}$ 1.149, de 11 de novembro de 2015. Aprova o Protocolo Clínico e Diretrizes Terapêuticas da Doença Celíaca. Brasília: Ministério da Saúde, 2015. Disponível em: http://portalarquivos.saude.gov.br/images/pdf/2015/novembro/13/Portaria-SAS-MS--1149-de-11-de-novembro-de-2015.pdf. Acesso em: 08 set. 2017.

BRITTO DA MOTTA, A. Idade e solidão: a velhice das mulheres. Revista Feminismos, Salvador, v. 6, n. 2, p. 88-96, maio-ago. 2018. Disponível em: 
http://portalseer.ufba.br/index.php/feminismos/article/view/30390/17912. Acesso em: 12 jan. 2020.

O final da vida no século XXI. Mediações, Londrina, v. 17 n. 2, p. 9-25, jul./dez. 2012.2 Disponível em: https://www.uel.br/revistas/uel/index.php/mediacoes/article/view/14339/11948. Acesso em: 30 abr. 2019.

$\begin{array}{cccc}\text {. Violências específicas aos idosos. Sinais Sociais, Rio de Janeiro, v. 8, n. 22, p. } \\ \text { 63-86, } & \text { maio/ago. } & \text { Disponível } & \text { em: }\end{array}$ http://www.academia.edu/6570327/Feminismo_e_Velhice. Acesso em: 29 abr. 2019.

BROUSSE, N.; MEIJER, J. W. Malignant complications of coeliac disease. Best Practice \& Research: Clinical Gastroenterology, London, v. 19, n. 3, p. 401-412, jun. 2005. Disponível em: http://www.ncbi.nlm.nih.gov/pubmed/15925845. Acesso em: 04 mar. 2019.

BRUHNS, H. T. A crise do lazer moderno e concepções de corpo. Licere, Belo Horizonte, v. 12, n. 4, p. 1-18, dez. 2009. Disponível em: http://periodicos.ufmg.br/index.php/licere/article/view/837. Acesso em: 26 jan. 2018.

Explorando o lazer contemporâneo: entre a razão e a emoção. Movimento, Porto Alegre, v. 10, n. 2, p.93-104, maio/ago. 2004. Disponível em: http://seer.ufrgs.br/Movimento/article/view/2835/1448. Acesso em: 26 jan. 2018.

Lazer, cultura e tecnologia: aspectos da globalização. Licere, Belo Horizonte, v. 1, n. 1, p. 77-94, set. 1998. Disponível em: http://periodicos.ufmg.br/index.php/licere/article/view/1558. Acesso em: 26 jan. 2018.

BRUHNS, Heloisa Turini. Lazer e ciências sociais: diálogos pertinentes. São Paulo: Chronos, 2002.

Lazer e tempo: buscando compreensões no processo de globalização. Licere, Belo Horizonte, v. 2, n. 1, p. 91-104, abr. 1999. Disponível em: http://periodicos.ufmg.br/index.php/licere/issue/view/97. Acesso em: 26 jan. 2018.

COSNES, J.; NION-LARMURIER, I. Les complications de la maladie cœliaque. Pathologie Biologie, Mayenne, v. 61, n. 2, p. e21-e26, abr. 2013. Disponível em: http://www.sciencedirect.com/science/article/abs/pii/S0369811411000484. Acesso em: 05 mar. 2019.

COUTINHO, R. X.; ACOSTA, M. A. F. Ambientes masculinos da terceira idade. Ciência \& Saúde Coletiva, Rio de Janeiro, v. 14, n. 4, p. 1111-1118, jul./ago. 2009. Disponível em: https://www.scielo.br/pdf/csc/v14n4/a12v14n4.pdf. Acesso em: 03 maio 2019.

CRANNEY, A. et al. Consequences of testing for celiac disease. Gastroenterology, Philadelphia, v. 128, n. 4, p. S109-S120, abr. 2005. Disponível em: http://www.gastrojournal.org/article/S0016-5085(05)00188-5/fulltext. Acesso em: 04 mar. 2019. 
DEBERT, G. G. A dissolução da vida adulta e a juventude como valor. Horizontes Antropológicos, Porto Alegre, ano 16, n. 34, p. 49-70, jul./dez. 2010. Disponível em: https://www.scielo.br/pdf/ha/v16n34/03.pdf. Acesso em: 01 maio 2019.

. Feminismo e velhice. Sinais Sociais, Rio de Janeiro, v. 8, n. 22, p. 15-38, maio/ago. 2013. Disponível em: http://www.academia.edu/6570327/Feminismo_e_Velhice. Acesso em: 29 abr. 2019.

Velho, terceira idade, idoso ou aposentado? Sobre diversos entendimentos acerca da velhice. Revista Coletiva, Recife, v. 5, n. 1, p. 1-4, nov. 2011. Disponível em:

http://www.academia.edu/6570229/Velho_terceira_idade_idoso_ou_aposentado_Sobre _diversos_entendimentos_acerca_da_velhice. Acesso em: 29 abr. 2019.

DEBORTOLI, J. A. O. Lazer, envelhecimento e participação social. Licere, Belo Horizonte, v. 15, n. 1, p. 1-29, mar. 2012. Disponível em: http://periodicos.ufmg.br/index.php/licere/article/view/739. Acesso em: 29 abr. 2019.

GASBARRINI, G. et al. Coeliac disease in the elderly. A multicentre Italian study. Gerontology, Innsbruck, v. 47, n. 6, p. 306-310, 2001. Disponível em: http://mohit.pure.elsevier.com/en/publications/coeliac-disease-in-the-elderly-a-multicentre-italianstudy. Acesso em: 13 out. 2017.

GIL, A. C. Métodos e técnicas de pesquisa social. 6. ed. São Paulo: Atlas, 2008.

GREEN, P. H. R.; LEBWOHL, B.; GREYWOODE, R. Celiac disease. Journal of Allergy and Clinical Immunology, Saint Louis, v. 135, n. 5, p. 1099-1106, maio 2015. Disponível em: http://www.jacionline.org/article/S0091-6749(15)00230-4/pdf. Acesso em: 13 out. 2017.

HANKEY, G. L.; HOLMES, G. K. T. Coeliac disease in the elderly. Gut, London, v. 35, p. 65-67, 1994. Disponível em: http://gut.bmj.com/content/gutjnl/35/1/65.full.pdf. Acesso em: 14 out. 2017.

HUSBY, S. et al. European Society for Pediatric Gastroenterology, Hepatology, and Nutrition Guidelines for the Diagnosis of Coeliac Disease. Journal of Pediatric Gastroenterology and Nutrition, Philadelphia, v. 54, n. 1, p. 136-160, jan. 2012. Disponível em: https://www.coeliac.ie/wpcontent/uploads/2015/05/European_Society_for_Pediatric_Gastroenterology.28.pdf. Acesso em: 04 mar. 2019.

IVARSSON, A. et al. High prevalence of undiagnosed coeliac disease in adults: a Swedish population-based study. Journal of Internal Medicine, Oxford, v. 245, p. 6368, 1999. Disponível em: http://onlinelibrary.wiley.com/doi/10.1046/j.13652796.1999.00403.x/epdf. Acesso em: 14 out. 2017.

KOTZE, L. M. S. Celiac disease in Brazilian patients: associations, complications and causes of death. Forty years of clinical experience. Arquivos de Gastroenterologia, São Paulo, v. 46, n. 4, p. 261-269, dez. 2009. Disponível em: http://www.scielo.br/pdf/ag/v46n4/04.pdf. Acesso em: 13 out. 2017. 
LOBO, B. et al. Usefulness of jejunal biopsy in the study of intestinal mal absorption in the elderly. Revista Española de Enfermedades Digestivas, Madrid, v. 96, n. 4, p. 259-264, abr. 2004. Disponível em: http://scielo.isciii.es/pdf/diges/v96n4/original4.pdf. Acesso em: 13 out. 2017.

LORENZO, C. M. Avaliação da qualidade de vida de crianças com doença celíaca e de seus pais:estudo caso controle. 2010. 66 f. Dissertação (Mestrado em Ciências Médicas) - Centro de Ciências da Saúde, Programa de Pós-Graduação em Ciências Médicas, Universidade Federal de Santa Catarina, Florianópolis, 2010. Disponível em: https://repositorio.ufsc.br/bitstream/handle/123456789/93675/291122.pdf?sequence=1. Acesso em: 13 out. 2017.

LUDVIGSSON, J. F. et al. The Oslo definitions for coeliac disease and related terms. Gut, London, v. 62, p. 43-52, 2013. Disponível em: https://www.ncbi.nlm.nih.gov/pmc/articles/PMC3440559/. Acesso em: 19 jan. 2018.

MAFFESOLI, M. A ordem das coisas: pensar a pós-modernidade. Rio de Janeiro: Forense, 2016.

A palavra do silêncio. São Paulo: Palas Athena, 2019.

Elogio da razão sensível. Petrópolis: Vozes, 1998.

MAFFESOLI, M. O conhecimento comum: introdução à sociologia compreensiva. $1^{\text {a }}$. reimpressão. Porto Alegre: Sulina, 2010.

O mistério da conjunção:ensaios sobre comunicação, corpo e socialidade. Porto Alegre: Sulina, 2009.

O tempo das tribos:o declínio do individualismo nas sociedades de massa. 5. ed. Rio de Janeiro: Forense, 2014.

O tempo retorna: formas elementares da pós-modernidade. Rio de Janeiro: Forense universitária, 2012.

2001 .

Sobre o nomadismo: vagabundagens pós-modernas. Rio de Janeiro: Record,

MARINHO, A. As diferentes interfaces da aventura na natureza: reflexões sobre a sociabilidade da vida contemporânea. 2006. 156 f. Tese (Doutorado em Educação Física) - Faculdade de Educação Física, Universidade Estadual de Campinas, Campinas, 2006. Disponível em: http://repositorio.unicamp.br/jspui/handle/REPOSIP/275255. Acesso em: 02 set. 2017.

MELLO, J. G.; VOTRE, S. J. Fatores que interferem na participação de homens idosos em programas de esporte e lazer. Pensar a Prática, Goiânia, v. 16, n. 4, p. 956-1270, out./dez. 2013. Disponível em: https//www.revistas.ufg.br/fef/article/view/22101/15688. Acesso em: 03 maio 2019.

MINAYO, M. C. S. O desafio do conhecimento: pesquisa qualitativa em saúde. 11. ed. São Paulo: Hucitec, 2008. 
MINAYO, M. C. S. Trabalho de campo: contexto de observação, interação e descoberta. In: MINAYO, M. C. S.; DESLANDES, S. F.; GOMES, R. (org.). Pesquisa social: teoria, método e criatividade. Petrópolis: Vozes, 2016. p. 61-78.

MOORE, L. R. "But we're not hypochondriacs": the changing shape of gluten-free dieting and the contested illness experience. Social Science \& Medicine, Boston, v. 105, p. 73-86, mar. 2014. Disponível em: http://doi.org/10.1016/j.socscimed.2014.01.009. Acesso em: 09 ago. 2019.

NASCIMENTO, A. B. Desenvolvimento de produto alimentício sem glúten elaborado a partir da percepção de consumidores celíacos. 2014. $182 \mathrm{f}$. Tese (Doutorado em Ciências dos Alimentos) - Centro de Ciências Agrárias, Programa de Pós-Graduação em Ciência dos Alimentos, Universidade Federal de Santa Catarina, Florianópolis, 2014.2 Disponível em: http://repositorio.ufsc.br/xmlui/handle/123456789/123304. Acesso em: 13 out. 2017.

.; FIATES, G. N. R.; TEIXEIRA, E. We want to be normal! Perceptions of a group of Brazilian consumers with coeliac disease on gluten-free bread buns. International Journal of Gastronomy and Food Science, v. 7, n. 1, p. 27-31, fev. $2017 . \quad$ Disponível em: http://nuppre.ufsc.br/files/2014/04/We_want_to_be_normal_Perceptions_of_a_group_o f_Bra-1.pdf. Acesso em: 13 out. 2017.

NITSCHKE, R. G. Pensando o nosso quotidiano contemporâneo e a promoção de famílias saudáveis. Ciência, Cuidado e Saúde, Maringá, v. 6, supl. 1, p. 24-26, 2007.

Uma viagem pelo mundo imaginal de ser família saudável no quotidiano em tempos pós-modernos: a descoberta dos laços de afeto como caminho. 1999. $478 \mathrm{f}$. Tese (Doutorado em Filosofia da Enfermagem) - Centro de Ciências da Saúde, Programa de Pós-Graduação em Enfermagem, Universidade Federal de Santa Catarina, Florianópolis, $1999 . \quad$ Disponível em: https://repositorio.ufsc.br/handle/123456789/80898. Acesso em: 02 set. 2017.

PEREIRA, C. C.; CORRÊA, P. H. S.; HALPERN, A. Relato de caso: doença celíaca recém-diagnosticada como fator agravante de osteoporose em mulher idosa. Arquivos Brasileiros de Endocrinologia \& Metabologia, São Paulo, v. 50, n. 6, p. 1127 1132, dez. 2006. Disponível em: https://www.scielo.br/pdf/abem/v50n6/a22v50n6.pdf. Acesso em: 13 out. 2017.

PICCOLO, G. M. Os caminhos dialéticos do envelhecimento e sua relação com a educação física contemporânea. Revista Brasileira de Geriatria e Gerontologia, Rio de Janeiro, v. 14, n. 1, p. 169-177, jan./mar. 2011. Disponível em: https://www.scielo.br/pdf/rbgg/v14n1/a17v14n1.pdf. Acesso em: 30 abr. 2019.

RIBEIRO, P. V. M. et al. Nutritional status variation and intestinal and extra intestinal symptomatology in patients with celiac disease and non-celiac gluten sensitivity given specialized dietary advice. Revista de Nutrição, Campinas, v. 30, n. 1, p. 57-67, fev. 2017. Disponível em: http://www.scielo.br/pdf/rn/v30n1/1415-5273-rn-30-0100057.pdf. Acesso em: 14 out. 2017. 
SANTOS, P. M. Lazer e grupos de convivência para idosos: um estudo sobre a participação de homens em Florianópolis (SC). 2015. 214 f. Dissertação (Mestrado em Educação Física) - Centro de Desportos, Programa de Pós-Graduação em Educação Física, Universidade Federal de Santa Catarina, Florianópolis, 2015. Disponível em: https://repositorio.ufsc.br/xmlui/handle/123456789/134668. Acesso em: 09 set. 2017.

.; MARINHO, A. Conteúdos culturais do lazer e participação masculina em grupos de convivência para idosos de Florianópolis (SC). Licere, Belo Horizonte, v. 18, p. 281-321, dez. 2015. Disponível em: https://periodicos.ufmg.br/index.php/licere/article/view/1164. Acesso em: 19 fev. 2020. DOI: https://doi.org/10.35699/1981-3171.2015.1164.

SCHATZMAN, L.; STRAUSS, A. L. Field research: strategies for a Natural Sociology. New Jersey: Prentice-Hall, 1973.

SVERKER, A.; HENSING, G.; HALLERT, C. 'Controlled by food'- lived experiences of coeliac disease. Journal of Human Nutrition and Dietetics, Oxford, v. 18, n. 3, p. 171-180, jun. 2005. Disponível em: https://doi.org/10.1111/j.1365-277X.2005.00591.x. Acesso em: 13 out. 2017.

VILPPULA, A. et al. Undetected coeliac disease in the elderly: A biopsy-proven population-based study. Digestive and Liver Disease, Milan, v. 40, p. 809-813, maio 2008. Disponível em: http://www.dldjournalonline.com/article/S1590-8658(08)00145X/pdf. Acesso em: 14 out. 2017.

VISCARDI, A. A. F. et al. Percepções de idosos sobre atividades de aventura na natureza. Licere, Belo Horizonte, v. 21, n. 2, p. 1-25, jun. 2018. Disponível em: https://periodicos.ufmg.br/index.php/licere/article/view/1808/1225. Acesso em: 19 fev. 2020. DOI: https://doi.org/10.35699/1981-3171.2018.1808.

WORLD GASTROENTEROLOGY ORGANISATION. Global Guidelines. Doença Celíaca. Milwaukee: WORLD GASTROENTEROLOGY ORGANISATION, 2012. 27 p. Disponível em: http://www.worldgastroenterology.org/UserFiles/file/guidelines/celiac-diseaseportuguese-2012.pdf. Acesso em: 13 out. 2017.

\section{Endereço das Autoras:}

Priscila Mari dos Santos Correia

Endereço Eletrônico: priscilamarisantos@ hotmail.com

Alcyane Marinho

Endereço Eletrônico: alcyane.marinho@hotmail.com 